\title{
TÖRTÉNETI KERTEK HELYSZÍNI KUTATÁSÁNAK TANULSÁGAI ${ }^{1}$ \\ RESULTS OF ON-SITE RESEARCH IN HISTORIC GARDENS ${ }^{1}$
}

$10.36249 / 52.2$

\section{ABSZTRAKT}

Az elmúlt két évtizedben jelentős számban növekedett a történeti kertek helyszíni kutatása Magyarországon. A kutatások minden esetben beruházásokhoz kertrekonstrukciókhoz müemléképületek, kastélyok és környezetük felúijtásához, helyreállítáś́hoz kapcsolódtak. Ezek során olyan tapasztalatok halmozódtak, halmozódhattak fel, amelyeket érdemes számba venni, áttekinteni, és a kutatótársak, a tájépítészek és az örökségvédelemben dolgozó énitészek, továbbá az érdeklődők elé tárni. E cikk keretében előbb röviden áttekintjiük a kutatások általános tapaszalatait, kitérve az előkészitő munkarészekré ́́s ́rintólegesent tó mgyalva

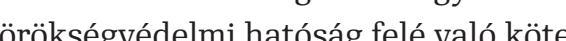
lezettségeket, - miközb fé jogi hatteret adó törvények ́́s kon jón hatletek szerinti szabalyoźst es eljarst,

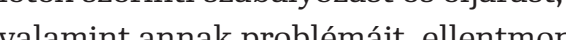
dásait nem tárgyaljêmáit, ellentmonkonkrét kert kutatásából jett dákkal illus kutásábol vett peLegutóbb Fas Ka low

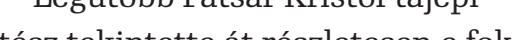
tész tekintette át részletesen e folyó irat hasábjain a történeti kertekben folytatott kutatások öss tett eljárásait ${ }^{2}$ 2oog-ben.
A KERTKUTATÁS ELŐKÉSZÍTÉSE, MODSZEREK ES FELADATOK

Egy adott történeti kert kutatásának alapja az a kerttörténeti tudományos dokumentáció, amely részletesen ta talmazza a kertre vonatkozó írott és képi forrásanyagot (1. kép), irzakiroda mat, esetleges terveket (ha volt korábban helyreállitís, annak a terveit is beleórtve) és az azokból levonh következtetéseket, például a régi tér-

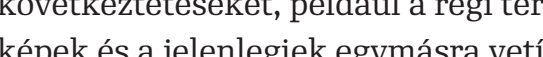
tése vagy egy-egy archív fotó bészíté elýn lo by hentácí széntón

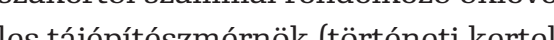
zzakt uilteten sult A tört́n ت̈v́́n oll yalon (fá, ajta, kor, allapot) el rogzten, tovabá az êt tetrészle ek maradvanyainak álapotát is, egységes értekleltarba foglalva. A novenenyallomány esetében le kell irni, hol végezheto régeszzeti módszerrel kutatás a törté

A taállomány kárositása nélkul. A helyszini kutatás módja és iránya fugg a feltárhato, felkutatható forrásanyag mennyiségetoto és milyenségetól: maradtak-e iratok, leirások, vis szaemlékezések, növénylajstromok,
ABSTRACT

Koszönettel tartozome cikkhez nyuj tott nelkülüzhetetetlen szakmai segitsé-
gért Klagyivik Mária és Bechtold Agnes 2 Fatsar Kristóf $A$ to

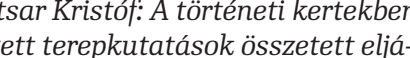
rásai, 4D Tajépitíszetiés Kertat
Folyoirat 13: pp. 36-55. (20og)
The number of on-site research in historic gardens has increased signiicantly in the last two decades in Hungary. In each case, the invin have been connected to investments, garden reconstructions, restorations garden reconstruns, restorations In these instances of research such experiences piled up that are such experionces piled up that are worth rewing and presenting to rects, architects, landscape archists working in heritage protection and all other interested people. This a This article firsty focres on the genco r of work and touching on the obligations to the his the protection autho (while nor the rules and pocedures, neither the problems and contradictions of the govennment regulations are negotiated here). The second half the article illustrates these with some specific examples of garden resea The last detailed publication on the complex methodology of historic garden research was writte by Kristóf Fatsar in 2009, which appeared also in this journal.
PREPARATION OF ON-SITE

GARDEN RESEARCH,

METHODOLOGY AND DUTIES

The basis of on-site research of a certain historic garden is the documentation of the history of the garden which contains in detail the written and image sources (Pic 1), technical literature plans (including also the plans for earlier resto(ntions rubber sheeting of archive and today's mers or the photo Today only landsape architects having registration number as experts (experts in monument consevation with (expers in mis entitled to make such documentations. Beyond the historical data, the existing veyon tho hor tion) and the preserved buit ton) and he proved bullt elenents are to be rocorded in an inventory. It also needs to be specified where archaeologcal research can be inplemented without impairing trees with historical value depend on the quantity and quality of available sources: have any written documents, descriptions, memoirs, vegetatio inventories, building contracts, plans (Pic. 2), drawings, photos, postcards
1 I owe thanks to Mária Klagyivik and Agnes Bechtold landscape architects for their essential professional help the a Fatsar Kristóf: A történeti ker végzett terepkutatások összetette eljarasai (A Comprehensive Approach to the Restoration of Historic Gardenss). $4 \mathrm{D}$
Tajépitészeti és Kertmüuészeti Folyoirat (4D Journal of Landscape Architecture), 4 (2oog), 13: pp. 36-55. 
épitkezési szerződések vagy tervrajzok (2. kép), rajzok, fotok, képeslapok? Az elkészult dokumentáció egyben a helyszíni kertkutatás hatóság fele való bejelentésenek dokumentuma is. Maga a kutatás két hasonló, de nem azonos módszerrel történhet. A föld alatt fekvő, elfedett részletek tekintetében nyivánvalóan régészeti a módszer, amenynyiben pedig az adott kutatandó kertbe felszín feletti épitmény, épület is áll - és azt, azokat is érinti a kutatás és majda a beruházás -, úgy a kutatási módszer a falkutatás (esetleg restaurátori kutatás) Fontos tudni, hogy a történeti kertek és maradványaik nagy része sem egészéb sem részleteikben nem régészeti korú, így a föld alatt levő elemei, maradvány nem képezik a régészettudomány tárgy A jelenlegi szabályozás alapján ugyanis csak az 1711-ig készïlt épült és utóbb fö́d lá került objektumok, tángyak tekinthetök régészeti koríaknak. Ennek megfelelóen a récészet oktán. a 18. és az azt követő századok története müvelódéstörténete müvészettörténete építészettörténete kerttörténete! Ugyanchó domán món a

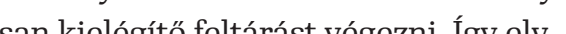
be kert kutatása igazi tean

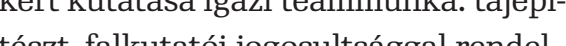
"ust " kezó szaken bont os oly regeszt kivan, aki tudással rondelkezlk a regeszeti korszakon túlnyuló múltrol is (18-19. száz es tudomásul veszi, hogy annak részleteit fel kell tárni es részletesen dokumentálni kell. Az itt bemutatott kutatá sok mindegyike ilyen teammunka volt. Ha a történeti kert ismert régészeti lelohelyen fekszik, vagy a kutatás sorà régészeti lelet, objektum kerül eló, akkor várható, hogy a 18-19. századi kert in- situ maradvanyai alatt régészeti korszakhoz kothetô leletek fekszenek. Azok feltárása már a régészeti feltárásra jogosult intézmennyt illeti, és a régészeti feltárás megkerülhetetlen, kivaltképp ha a tervezett kivitelezés mélysége

erinti a régészeti korú maradványokat.

KERTTÖRTÉNETI TUDOMÁNYOS

DOKUMENTÁCIÓ

ÉS A HELYSZÍNI KUTATÁS

tudományos dokumentáció elkészitésével párhuzamosan (vagy utána) szükséges és hasznos, ha a geodéziai felmé rés és más müszeres mérések (talajrada régészeti geofizikai mérés) is elkészülnek. Míg a geodézia értelemszerúen az egész kertről készül, a geofizikai vagy más müszeres mérések helyének meg határozáśában már nagy szerepet játszik képi forrásanyag ismerete és a teriulet részletes felderítése bejérés és a terulet tóbbi szemén archív fotókkal képeslapozkal, katazzeri vagy egyéb térképekkel-je per épített résekt, eges fortásbol lsmert heti. Egyfajta a régészet módszerei köziil atvettés a ketere alkalnat tejénás a Mindez nagyban függ attól eja va min ogýn Análtalán lehetốvé teszie a bejáns

a a felán lehotové teszi-e a bejárást?

A felszínen megfigyelt nyomok - téglaomladék, az aljnoveenyzeten át is erzekekehetó kavicsozott felszin, mohos faragott kövek egy bozotosban, vagy egyszerúen egy domboldalba vágott, „útszerủen” fut terepsáv, a lejtőre merólegesen fekvô, endezettnek tűnő kősorok - mindmind a forrasokbbol ismert vagy eppen smeretlen objektumra utalhatnak

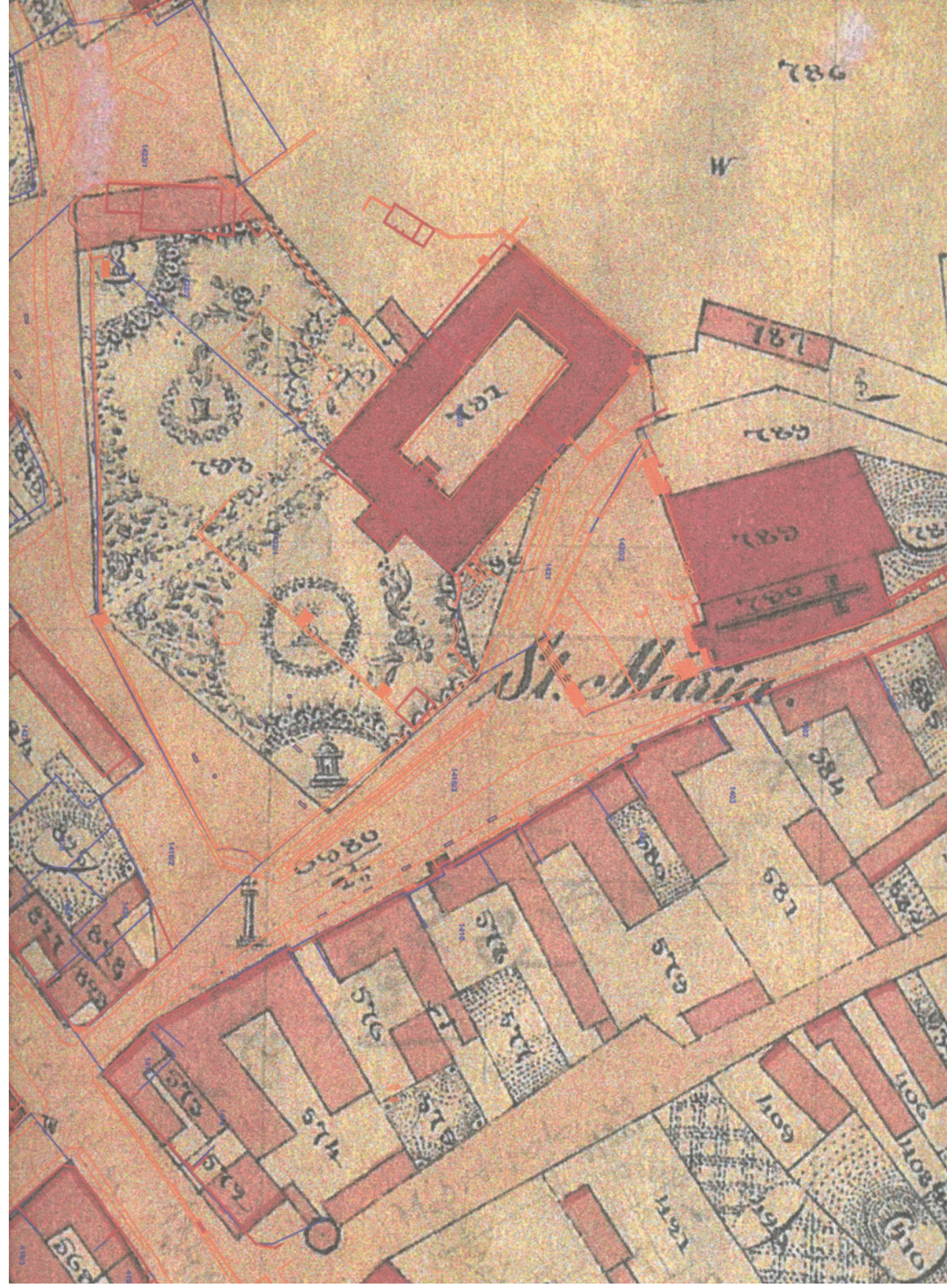

remained? The scientific documentation also needs to be presented for the authorities when notifying them about the planned on-site research. On-site research can be done with two similar but not iden Looking for forgotten details under the ground is done with archaeological methods while existing built elements edifices above ground can be explored by building archaeology (or perhaps by building archaeology (or perhaps importanto know that in most of the historic gardens or their most of the historic gardens or their age the elements under the ground are not subject for archaeology in the classic sense:ony 1711 can be regarded as archaeological nes according to the Hungarian legisation in force. Thus, history, art history, rchitectural and garden history of the th century and later times are not subjects in archaeological education. Notwithstanding, satisfying and scienearch under the ground can only ithented with archaeological methods. As a result, the research of detaled As a rult, the detalle in bulding arche aros bout the culs wave knowled (18- ch a know the of later this tim c. and know that the detalls of dis time also need to be excavated and ological site or archaeological findings hering all the examples shown

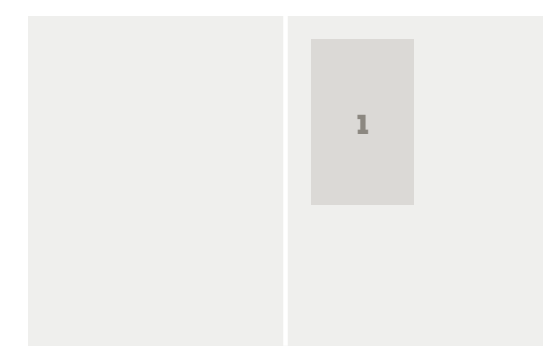

1. kép/pict.:

palota kertie /

Garden of the Bishop's
Palace, Sümeg 

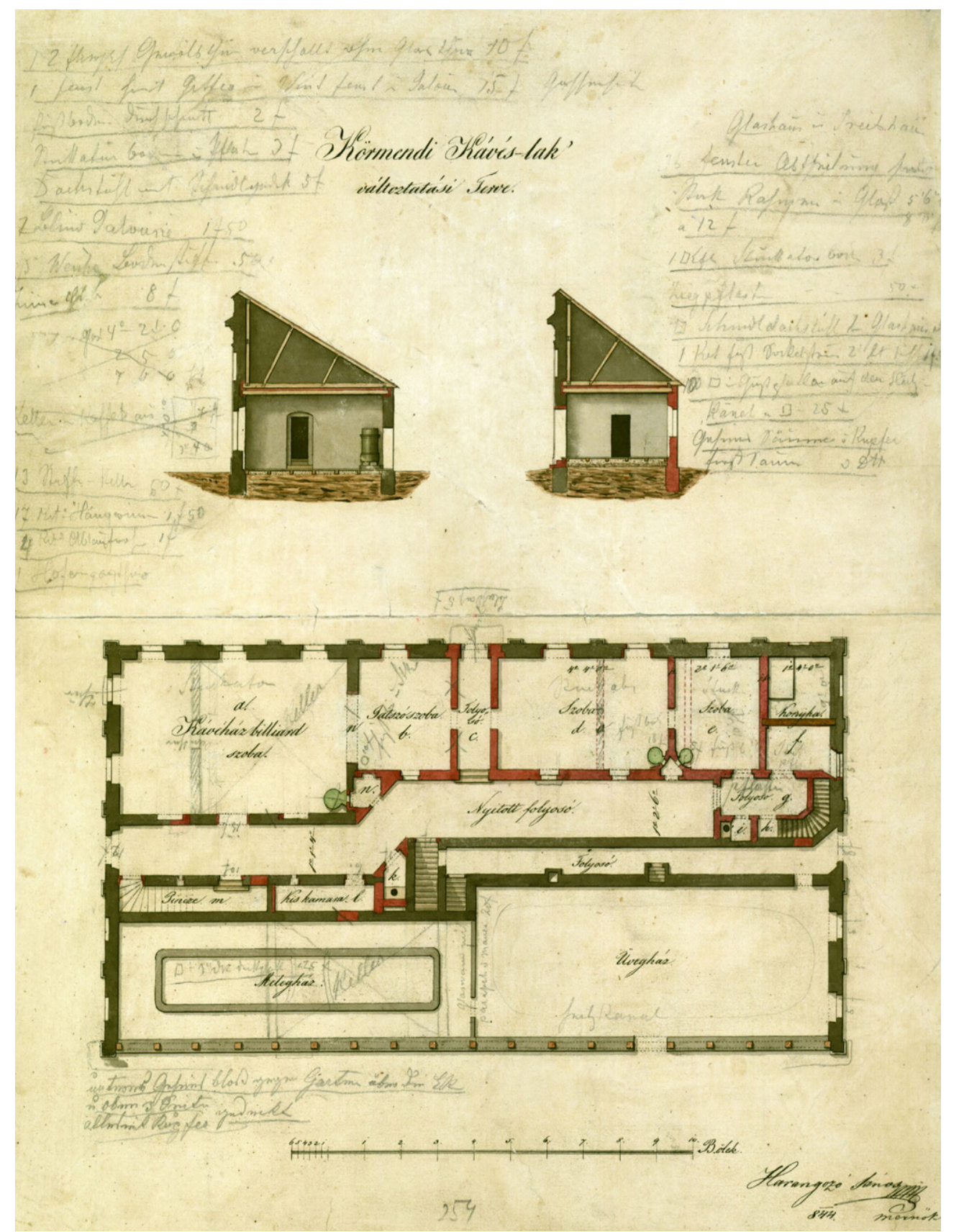

Amennyiben a bejárás eredményes, a lokalizált részletek geodéziai bemérés megtörténhet, illetve ahol indokolt, ott elkészülhet az említett müszeres mérés is. Ez utóbici tott, esetleg ha lehetséses, a botrotto sarjadékoktól megtisztított „sík” területeken végzendő el, nagy felületeken. A bejárás, a geodézia, az egyéb műszeres mérések és a képi forrásanyag összevetese után kerulhet sor a helyszíni kutatás helyeinek és módszerének a meghatározására. Kiemelten fo tos az is, hogy az adott kertnél megjelenó beruházoi es tervezói szándé milyen, mi a célja, mit akar helyreállítani, mire van kapacitása. Eltérő módszert kíván, ha csupán meg kívánunk arról győződni, hogy az adott objektum például egy szökőkút - valóban ott van-

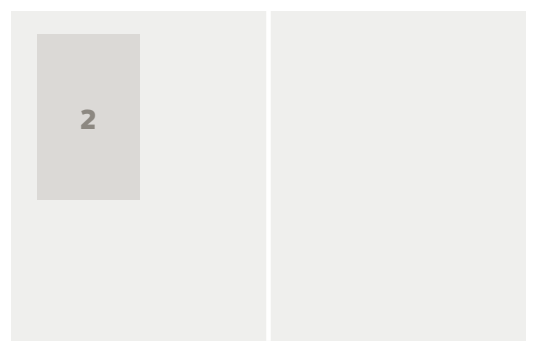

\section{2. képp/pict.}

Batthyány-kastély,
Naranchhaz tervrajzza 1844-bôl (T4_oosjav) / Plan of
the orangerie of the orangerie of
Batthyány Castle,
Körmend, 1844 occur during the excavation, then a layer of archaeological findings $c$ be expected under the garden of the 18-19th century. The exploration of the findings concerns officially the institute entitled to archaeological excavations, and the excavation will be unavoidable especially if the extent and depth of the forthcoming construction work reach the archaeological remnants.

THE SCIENTIFIC DOCUMENTATION OF THE HISTORY OF THE GARDEN AND ON-SITE RESEARCH

In addition to the scientific documentation, the land survey and other measurements like archaeological geophysical surveys (e.g. ground-penetrating radar) are inevitable to be executed. While

land surveying is obviously made on the whole spot, other measurements are limited to certain parts of the area, in the localization of which the knowledge of image sources and detailed exploration of the spot plays a great role. The latter - on-site inspection with the help of archive photos, postcards, cadastral or other maps - may result in great discovthe exc place of which were un before This is a kind of field survey took over from the methods of archeology and applied for gath und forest emer of garden or the young sed or the lo sh llow this kind of on-site examination. Tras on the suface - bannation. Traces on the surface - brick fractures, gravely surface perceived even carved stones in the shrubbery or just the ground cut into the hillside like a path and lines of arranged stones perpendicularly to the slope - may al refer to some objects, either known from historical sources or unknown. If a field survey has results, the land survey of the elements can be done and where it is justifiable, geophysica prospection can also be carried out. The latter should preferably be done on large open and possibly clean (i. e. without shrubberies), flat areas.

The exact places and methods of on-site research can be specified after summarizing the results of the abovementioned field survey, land survey, geophysics and image sources. The investors' and designers' intentions, aims, the subject of renovation and their capacity are also of great importance. A different method is needed if we only want to make sure that the particular object - a fountain for instance - is actually located where

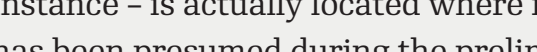
in ory observations, or if we wanto explore the entire fountain, since the plan may include restorion. The rcher bjects to surface) is only justifable where so sure is an justifable where arth Nevertheless, no matter how

the prelininary resear of of a garden, the mar a the histry revealed such buit elents be not been antipinte During the on bjects a objects above the surface should also be examined and if they are already known and big enough, building archaeology is needed as well. The methods of archaeology and building 
is szükséges. A régészet és a falkutatás (épületkutatás) módszere itt kapcsolódik össze annak érdekében, hogy az adott történeti kert minden épített rés letéről kielégítő ismeretünk legyen.

A KERTKUTATÁS MÓDSZERTANA

Miután megtörtént az írott és képi forrásanyag osszegyujtese, a kulonfele múszeres mérések, a terepbejárás, továbbá a kerttörténeti tudományos dokumentációt a helyszíni kutatás bejelentésènek kötelező mellékleteként (68/2018-as Kormányrendelet 12. melléklete szerinti összeállitásban) benyúitották az örökségvédelmi hatóságnak, megkezdődhet a helyszíni kertkutatás. Amenynyiben falkutatás is szükséges, az adott kerti épületekről el kell készíteni az ép téstörténeti tudományos dokumentációt, és a helyszíni munka bejelentésekén azt (is) meg kell küldeni a hatóśágnak A régészeti feltárás során a módszert a kutatandó kert adottságaihoz kell igazitani, így amennyiben a kert többrétegü azaz ismert, hogy többszörös átépítés ment keresztül - úgy mindig mér lendő, hogy például egy tújḱni one-

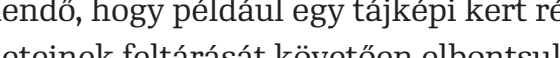
azokat anna érdekébn hogy a koráb barokk kertet feltáriuk. Mér a is, hogy teljesn feltárume

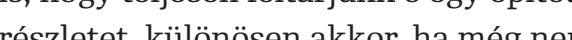
eszletet, kulonosen akkor, ha més nem Amenniben ugyas csún tudni Ańnk, vabyans csupán tudni szeismert objektum, elegendő lehet egyetlen kutató

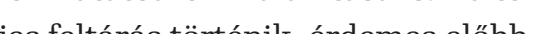
jes feltarás tortonil, endomes elobb egy árokkal átvágni a teruletet, hogy tajèkozódjunk a kutatott épitmény szerkezetéról, allapotáról. Majd osszevetve az in-situ részleteket a rá vonatkozó kép forrásanyaggal és a szükséges következtetéseket levonva kezdodhet a teljes felületủ régészeti módszerủ feltárás. Egy adott kert kutatásánál a feltêtelezhető roncsolódás, pusztulás mér- téke is számittásba veendö, hiszen gy városi környezetben álló olyan terulet, amelyen folyamatos épitkezések, atépitések, kömúkialakítások tortentek, maskeepp kutatható, mint egy park, kert, ahol hosszab deje nem történt semmilyen komoyabb földmunkával járó b A régészeti módszerrel történỏ kutatás szerves részét képezi a feltárt részletek dokumentálása rajzban, fotón és leírásban. Tekintettel egy kert nagy kiterjedésére kikerülhetetlen a kutatóárkok, szelvények és az objektumok alaprajzi rendszeré nek rögzitésekor a geodéziai felmérés. A földfelszín felett álló építmények épületek esetén falkutatás szükséges, amelynek során a belső épületstruktúrák, szerkezeti megoldások, nyilásrendszerek, járószintek ugyanúgy vizsgálandók, mint a külső és belső vakolat, faragott kô vagy éppen vegyes anyagù architektúrák kifestések és mindezek korszakai, átépítései. A falkutatásnak az adott épület, építmény teljességére $\mathrm{k}$ kell teriednie és értelemszerüen ott, aho z szïkséges, a járószintek alatt régészeti módszerrel kell a kutatást kiegészteni. Mivel a kertekben álló ́́pületek éptettsége igen eltéró lehet magát a falkutáśs mindenkor az adott és egyed pítmény kell alla azazi, hiszen nódja van egy nagy meren narazo

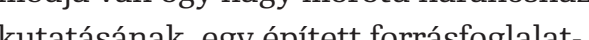
kutatásanak, egy éptett forrásfoglalat-

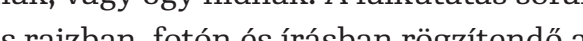
mujk folya Fontos, hogy a kutatás során a tervezők is bekapcsolódjanak annak ezok is bekapesolodjanak annak han ismerhessék teltárt allapotában ismerhessek meg az egykori kertet es a benne foglalt épuleteket, épitményeket annak erdekében, hogy a feltárulo, korabban esetleg nem ismert részleteket bevonhassák a helyrellitásba, a tervezés folyamatába. A helyszíni kutatás eredményeit kutatási dokumentáció kell, hogy összefoglalja, amely egyben a hatóság felé archaeology are combined here in orde to gain satisfying knowledge of all the built elements of a historic garden.

METHODS OF GARDEN RESEARCH

The on-site garden research can begin after collecting the written and image sources, doing the measurements, field surveys and also the scientific documentation of the history of the garden has been presented to the heritage protection authority as the obligatory appendix of the declaration of on-site research (following the regulations of the 12th appendix of the 68/2018 government regulation). Inasmuch as buildin archaeology is needed, the scientific documentation of the history of the certain buildings and its presentation for the authority is also needed. The methods of excavations need to be adjusted to the characteristics of the garden. Thus, in those cases when the garden is multi-layered, $i$. gone through many rebuilding and transformations, it always needs to considered whether, for instance the details of a landscape garden should detals of a lished in onder to un sould earlier baroque garden. It hhould also be considered to fully unfold a buit cocilly if it has not yet decided to be present ho not yet decided to be present or restored if the object known fom the kow r the object known from the sources really exists a a certan location, it is enough to have only one ditch. If a complete excavion happens, on the other hand, it is worth cutting a ditch across the whole area to orient oursel about the structures and ther condtions. Then, after comparing the in situ detalls with the image sources and drawing the conclusions, the excavation on the whole surface can begin. The extent of destruction of a garden should also be taken into account, because an urban area, where extensive construction and reconsruction works have happ public utilities have been laid, can be explored differently from a park where hardly any earthworks have

happened in the last 60 years.

The documentation (drawings, photos, description) of the excavated details an integral part of the research work Due to the large area of a garden, it is inevitable to localize the archaeological ditches and objects by land surveying. Building archaeology is needed in the case of those edifices which are above ground. On these edifices, the inner structures, doors and windows, floors are to be examined, as well as the inner or outer plastering, the architecture made of carved stone or mixed materials, wall paintings and all the periods and changes of the above mentioned. Building archaeology should cover the whole edifice and where it is necessary, methods of archaeology should also be used under the floor. As the buildings of a garden are variable, the methods should always be defined individually according to the certain building the methods to examine a big Orangerie built catchment or a bridge differ fro cach other. The working process and the explored details should be documented on drawings, photos and de

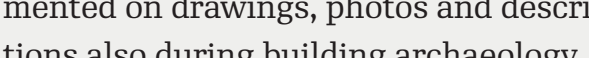

It is important for landscape architect to join the pross of resear in to cognize the garden and its edifics in their revela case they can add such detais into their cose, they can add such detals into the conservation or The no have been know earler. The results of garden archaeology have to be written in research documentation, which - together with the scientific documentation of the history of the garden - is a compulsory appendix of the plans for the authorisation procedure. The documentations include a suggestion for conser- 
benyúitandó helyreállitási terv előírt melléklete is a korábban már említett kerttörténeti tudományos dokumentá cióval együtt. A kutatási dokumentációba tartozik egy helyreállitási javaslat, amely felhivja a beruházo és a tervezo figyelmét arra, mely részletek megózése szükséges - akár úgy is, hogy bem tatásra nem, ám állapotát megóvó elfedésre kerül. E dokumentációban van lehetőség az építéstörténeti dokument ciók értékleltárának kiegészitésére is. Végül a meginduló kivitelezés során kiemelten fontos, hogy elsősorban annak földmunkával, falbontással járó szakaszában a kutatói munka folytatódjék. Hiszen például egy tervezett közmüárok nyomvonala sokszor még nem isme a kutatás idején és annak nem is feladata, hogy azt mintegy előre megássa. Egy anyagában már nem megőrizhető történeti út új rétegrenddel való kialakítása során is, elöbb elbontásra kerül a történeti út roncsa, amit dokumentálni kell. Ez utóbbi esetben pont a teljes felszínre kiterjedő bontás során les azonosítható és helyreállítható a pontos nyomvonal. Épületeknél is szuiksé gessé válhat az eredeti szerkezetnek például statikai okokból való meghon-

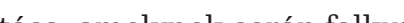
gyelést és dokumentálást kell végezni.

\section{RÖVID ESETTANULMÁNYOK}

Az alábbiakban (néhány hazai törté neti kert kutatásából kiemelt jellegzetes példákat mutatunk be, amelyek alkalnasak a kertre gészeti kutatások módszereiner.

\section{Füzérradvány, Károlyi-kastély}

történeti kertje ${ }^{3}$ (3.kép)

A tájképi kert kutatásának fontos része volt az egykori utak és a csatlakozó ép mények - folyókák, átereszek, hidak vizsgálata. A kert bejárása során az utak részben használatuk, részben a terepadottságok miatt; voltak azonban olyan szakaszok is, ahol vagy elfedettségük, vagy a felnott bozót miatt csak feltét ezhetó volt az ùtvonal a képi forráso alapján. Az utakhoz csatlakozó faszerkezetú hidak kőből rakott hídfơii a vízmosásmedrek bejárása során még a bozótosban is felismerhetök voltak. Az utak esetében keresztirányú árkokat bontottunk, ügyelve, hogy a meglévő épített felszín ne roncsolódjon. Aho nem volt komolyabb épített felszín, ott a keresztárkok mélyebb kialakitásával tártuk fel az egykori utak rétegrendjét. A kutatóárkokat - a kerti utak célszerủ kutatási módszerének megfelelően - mindenhol szélesebbre vettük az utaknál, hogy a szegélyek is meghatározhatók legyenek. Szinte minden út mellett találtunk folyókákat és átereszeket. A park egyetlen nagy méretú, 19 . századi kőhídián falkutatást is végeztünk, egykori vakolatainak színét és anyagát restaurátori vizscálat tálapí totta meg. A híd járófelületén régé szeti módszerrel távolítottuk el a nár kódott humuszt hogy egykori szerkezetét, elemeinek (pl. kerékvetók) elyét lemen (pl. kerékvetök

A híd közelében álló dombon egy-

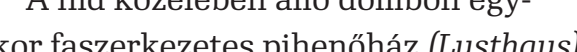
kor faszerkezetes pihenőház (Lusthaus) helyezredett el, itt nagy feluleten régehelyét Sem cölöplyukak sem egyé

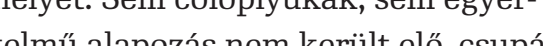

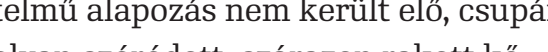
sork, an. Ṕl ér galhattak. Pelda ez arra, hogy a konynyuszoces nyomot hagynak maguk után, és teljes elbontásukat kovetóen sokszor már ne lehet pontos helyuket meghatároz A kastély elöterében kis méretủ pleasure ground helyezkedik el, ennek untatása során sikerult az egykori, nyír puszpángsor sekély ültetési árkait és az övezó kozuzualekos utak maradványait is feltárni. Regészeti es falkutatási módszerrel vizsgáltuk az e kert-
3 A részletes kerttörténeti dokumentàjektról részletes könyu készült: Alfö́ldy Gabor: A füzérradványi Károlyi-kastél parkja, Budapest, 2015. A történeti ke
helyszzini kutatásáról: Koppón Andros A füzérradványi kastélyparark kutatás és annak tanulságai, in: Jósa András Muzeum Evkönyve LIX.evef.I., Nyíregyfolytatódó kutatását $G$.Arvai Z tajepitesz es Koppany András iraznuito

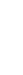

details that need to be preserved even if it may not be presented, jus covered back. The research documentation can also continue and complete the inventory made before Finally, it is also very important that the research should continue durin the construction works, especially in those phases when earthworks and demolitions happen. For instance, the planned tracks of public utilities are usually not known at the time of research but still can unfold historic elements. Furthermore, when making the new structure of a historic garden path, the materials of which cannot be preserved any more, the remains of the old structure are often demolished, which also need to be documented first. In this latter case, the exact track of the original path can be identified precisely during the demolition process which concerns the whole surface. In the case of buildings, the original structures may need to be changed, for static reasons for example, in which case observation and documentation has to be done.

(a)

In the following, some examples from historic garden research in Hungary will be presented with which the methods and possibilities of garden archaeology can be demonstrated.

Füzérradvány, historic garden

of Károlyi Manor ${ }^{3}$ (Pic. 3)

The examination of the former paths and connecting edifices like drainage channels, culverts and bridges was an important part of the on-site research. Most of the historic paths were easy to be identified due to their usage or the morphology of the ground, but there were also some sections where the location was presumably only with the help of the ina prost were covered or shrubby. However, the stoned bridgeheads of wooden bridges could be identified even in the shrubbery when inspecting the gully courses. We dug ditches traverse to the paths, taking care that the remaining historic surface of the paths does not get damaged. Where there was no an intensely built surface, we unfolded the layer structure of the paths by making deeper ditches. As it is recommended in case of excavating garden paths, the ditches were always longer than the width of the certain path, so that the edges could also be defined. We found drainage channels and culverts in almost all cases.

We also applied building archaeology in case of the only stone bridge of the park, built in the 19th century, while the colours and materials of its plaster were defined by the restorers examinations. The humus was removed with archaeological methods from its read surface after which its structu and the location of its elements (e $g$. safety posts) could be ascertained

Once there was a wooden pavilion (Lusthaus) near the bridge on the top of the hill, which we tried to localize with archaeological methods on a large surface Neither posthos built substructure was fouth onty the races of dry stone rows fnot bedded

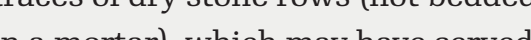
ss the foundations of the building. This is a god examp for the fact The lightwe little mark and their en love very te den cannot be defhed if they have

A som plath

A small pleasure ground lies in front of the manor house, the research of which unfolded the shallow planting furrows of the former clipped hedges of boxes and the remnants of the surrounding rubble path. We examined the stairs leading to the pleasure ground and their substructure both with the methods of archae-
ology and building archaeology.
3 The scientific documentation of the history of the garden was written by Gábor
Alföldy. A detailed book of the whole project was published: Alföldy Gábor: A füzerrradványi Károlyi-kastély parkja (Ine Park of the Károlyi Manor, Fuzér about the on-site research of the garden: Koppány András: A füzérradvány ságai (On-site research of the park of Károlyi Manor, Füzérradványl. In: Iósa András Múzeum Évkönyve (Almanac of Jósa András Museum) LIX., Nyíregyház 2017. p. 393-399.; The newest resear-
ches in 2016 were led by Zsuzsa G. Arve landscape architect and András Kop

pány. 
4. kép/pict.:

Iszkaszentgyörgy,
tânallepcsö/

$\begin{array}{ll}\begin{array}{ll}\text { Fuzerradvány, } \\ \text { unfolded garden path }\end{array} & \begin{array}{l}\text { Iszkaszentgyörgy, } \\ \text { retaining wall with }\end{array} \\ \end{array}$

with draina

retaining wall wi
staicase

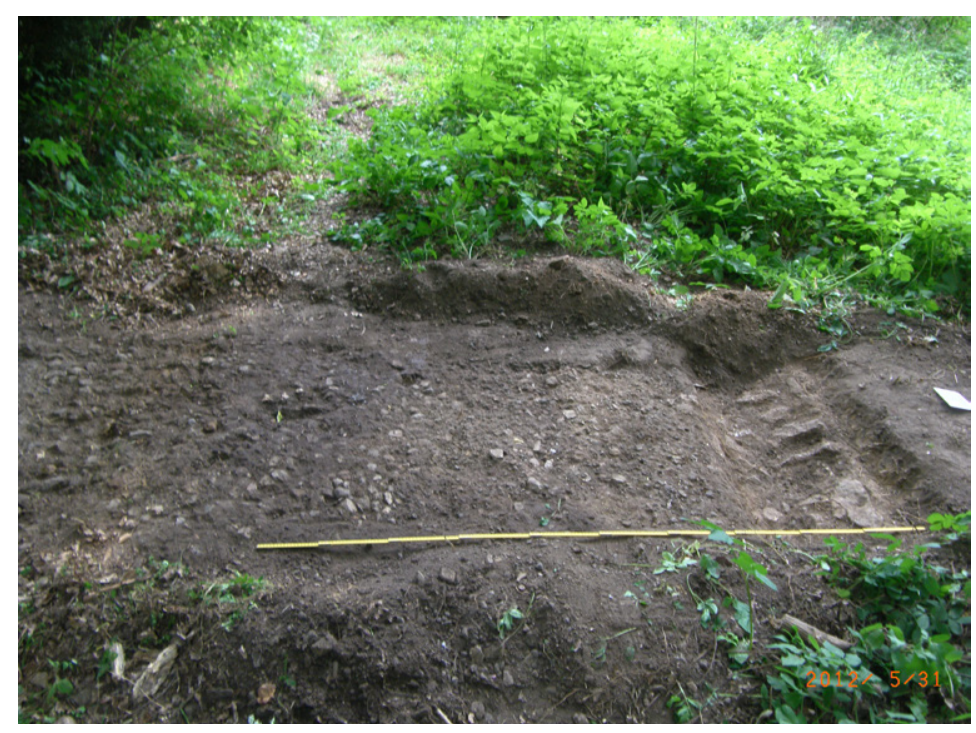

kedő és feltételezett lejáratokat. A feltarás során lépcsook visszabontott téglastruktúrája került eló a későbbi tudatos elfedés és a rárakódott humuszos rétegek alól. Jellegzetes példa ez arra, hogy a komolyabb alappal megépített történeti szerkezetek roncsai mindig nagyobb eséllyel lokalizálhatók és tárhatók fel.

\section{Körmend, Batthyány-kastély}

un. északi kert ${ }^{5}$ (5.kép)

A kastély épületegyüttesének főépüle-

tétól - egykori középkori vár - északr

elhelyezkedó terïleten a képi és az

elhelyezkedô teruleten a képi és az

ól kezdve találh tó áptett kert.

szakainak egymás felett fekvő réteget

és részleteit löbb múszeres móńs-

selés a képi forrásanyag összevetésé-

vel próbáltuk megháńrozni, nojder-

követően régészeti módszer

to

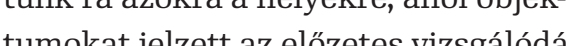
tanutścos, hogy a felszín a jelón leg is használt utak kivétéver

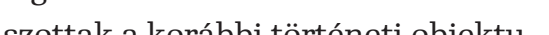

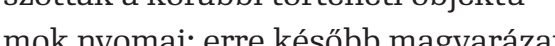
a dott, hogy a kutatón adott, hogy a kutatónkok nindegyike ben a legfelsó vaskos foldréteg egységesen kevert tormelekretegkent jelentkezett. Ez pedig nagy teruletú, moder tereprendezésre utal. A kevert réteg alatt azonban feltártuk a 18-19. századi épített kertrészek müszeres méréssel jelzett maradványait. A maradványokról nem allt rendelkezésünkre irott vag képi forrásanyag, azok meglétét előzetesen kizárólag a müszeres mérés alapján
4 Takács Katalin-Gecséné Tar Imola: Amadé-Bajzath-Pappenheim kastély, délyezési tervdokumentáció részekén készült, publikálatlan kézirat), 108.p;

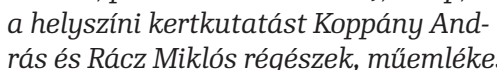
szakértök irányitották.

5 A kerttörténeti tudományos dokumentációt Klagyivivik Mária tájépitész a helyszini hutatói munk Klagyivik Mária tajépítész, Nádai Zsófia ès Hegy Dora régeszen (Budavär Kft.) iranyitoták, konzulens Koppány András régés,
müemléki szakértón (MEM-MDK) volt.

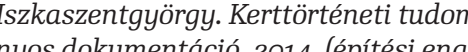

All of these were documented in details, that was found to be vital since the stone bridge was destroyed during the construction works.

Iszkaszentgörgy, historic garden of the Amadé-Bajzáth-Pappenheim Mansion $^{4}$ (Pic. 4)

In the terraced formal garden southea from the main building in Iszkaszentgyörgy, we both examined the stairs ramps which led to the terra stairs and each other and localized the form paths of the terraces. The presumed track of the paths had heen based on image sources, after whish we unfolded The retaining wall closest to the mansion is well-bitt construction ctones in which a staicase is installed stones in whe a starcase is installod parallet the wall The stass are leach toa wod resting placewith bench, bounded by an iro gate from the lower tera da modem purtan edifce is a doninat element of this part of the garden, therefore bullding archaeological research with the description of the building methods, a detailed drawing and photos could not be omitted. We examined the former and suppos elements that led to the lower terrace consciously and the humus coating. unfolded quite large surfaces shallo we and the with archaeological methods. The excvation unfolded the brick structure of stairs from under the coverage ma
This is a typical example that remnants of those historic structures that have vely to be localized and unfolded.

Körmend, Batthyány Castle, the so-called northern garden ${ }^{5}$ (Pic. 5 According to written and image sources, the garden at the northern side of the main building a former castle in the Middle Ages, has been existing since the 18 th century. We tried to define the layers of its different eras lying abe ach other first by analysing ima sources and with geophysical measurements, then by excavating those locawe was quite wormer surface except for those paths which in are in use today, the explanation for ballo ll of the ditches. This sugsts colin porary leviling of the grosts in a porary levelling of the ground in a large r. Nes che gth centuries indicated by the geophyscal survey under this layer. However, we did not have any written or mage sources of these objects, we only got to know them beforehand due to the measurements. These experiences justify that using various approache Thevitable in garden research. The northern garden is bounded by a
huge building, used as Orangerie earlier
4 Takács Katalin - Gecséné Tar Imola: Amadé-Bajzath-Pappenheim kastély, mányos dokumentáció (Amadé-Bazáth-Pappenheim Mansion, Iszkaszentgyörgy. Scientific Documentation of the History of the Garden). 2014. (Unpublistion plans made for the authorities to get a building permit.) The on-site research was led by András Koppány and Mik-
lós Rácz archaeologists and experts in monument conservation. tory of the garden was made by Mária Klagyivik lo ditect (NÖF No was led by Mária Klagyivivik landscape architect, Zsófia Nádai and Dóra Hegyi archaeologists (Budavari Nonprofit Lta
with András Koppán expert in monument conservaation (MÉM $M D K)$ as consultant. 

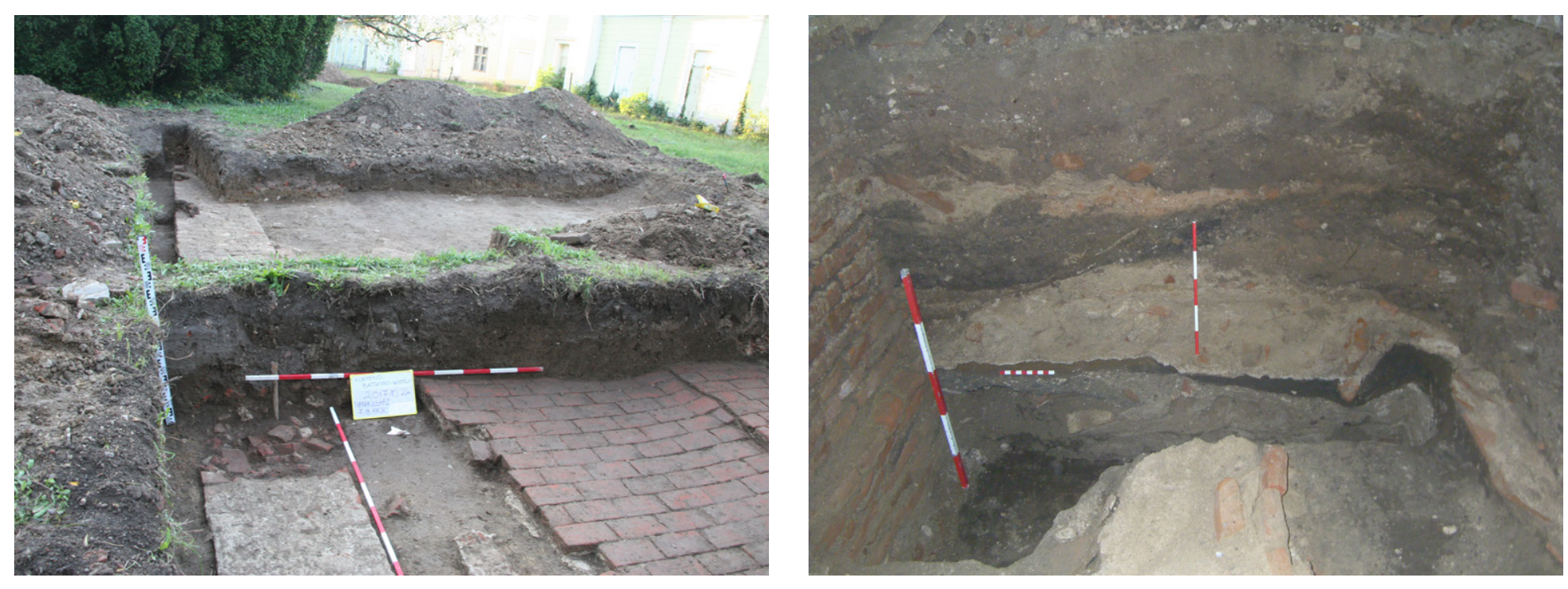

ismertük. E tapasztalatok is igazolják, hogy szükséges a többfêle elózetes me közelítési mód együttes alkalmazása. Az északi kertet nagy méretú, egykor narancsházként (orangerie) szolgált ép let határolja. A gazdag írott és képi forrásanyag alapján az épület története felépítése, visszabontása, átalakításai viszonylag pontosan felvázolható Így a kutatást is pontosan meg lehetett tervezni: a föld alatt levő, visszabontott egykori üvegházakat és fütőrendszerüket régészeti módszerrel tártuk fel, azálló épületeken pedig falkutatást végeztü hogy aztón végül rajzban fotón és részletes léŕśsban összegezhessulk a törté neti források és az in situ részletek alapján hogyan is nézett ki az egykoríntés mit lo

\section{Fertőd, Eszterházy-kastély}

\section{Képtár ${ }^{7}$ (6.kép)}

A kastély főépületéhez tartozó nyugati A vágzett, járószintek ala kutatás tanulságos részleteket tárt fel. Maga a kutatás az épuletrész visszabonéche

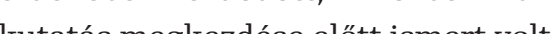
kutatás negkezdose eloutt ismert volt a kepi es irott forrasanyagból, hogy a 18 századi épuletreszt egy korábbi, szintên 18. szazzadi kerteszre eptettek rá. Igy amikor viszonylag mélyen, az épület falalapozása által vágua, kerti út és rádöntött vakolt architektúrával rendekezö, cserépfedéses keritésroncs kerül elo, azonositható és korszakolható volt a forrásanyag ismeretében. Jól példázza ez

a feltárás, hogy egy, az egymásra követezó periódusok során „terjeszkedo kas telyépulet alatt erdemes feltételezni, keresni, feltárni a korábbi épületkorsza kornyezetének, kertjének maradványait.

Szabadkígyós, Wenckheim-kastély történeti kertje ${ }^{8}$ (7.kép)

A kastélypark bejárása és a képi forrásanyag helyszíni használata együttesen vezetett eredményre egyes objektumok azonosításában.

A parkban az egykori un babaház (kis méretú, idillikus parasztház jelle gel) romjainak feltételezhetón helyét az 187o-es évekből származó helyszínrazokkal lehetett a bozótos han azonostani. Téglatörmelék és az egykori külsô eület holýt Az árokkal voló róbontás után a humuszal kevert rápunonún a no las a falak es padlo kerdt elo, ennok ismeményt feltárni, hogy in situ részletei nem A kert kataszteri térképén jelzett, A kerton nogyb méretú tó partteterén

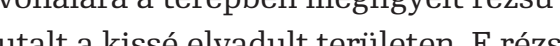
utalt a kissé elvadult teruleten. E rézsuure merolegesen húzott hosszú árokban tárult a tó egykori partjanak kosorora, Jezve. valóban nagyobb volt egykor. Vizsgáltuk az egykori utak nyomvonalat is, amelyek egy része vékony humuséteg alól volt sejtheto, sigy nem tul mely ákokkal vágtuk át szerkezetuket. Kis méretú árkokban bontottunk rá az
6 Erdélyi Erika - Koppány András, A kòrmendi Batthyany-kastély narancsházá zadai, Körmend - Szombathely zoés. 7 A Képtár falkutatását és a hozzá tar tozojarososzintek alatti kutatást Koppán Ahas es Rácz Miklós régészek, müen$\boldsymbol{8}$ A kerttörténeti tudományos dokum tációt Bechtold Ágnes és Németh Zita

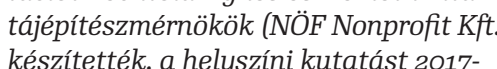
ben Bechtold Áanes tájépitész, Nádai Zsófia és Hegyi Dóra régészek (Budavar Kft.) és Koppany András régész müem-
Its history - building, partial demolition, transformation - can be delineated qu exactly on the basis of the written and image sources. Therefore, the research could also be planned exactly: the demo ished greenhouses and their heating system have been explored by archaeological methods, while we applied building archaeology in case of the stillstanding walls. Then, on the basis of sources and in situ elements, detailed documentation with drawings, descriptions and photos summarised how the former building loored like what could be reconstructed of it:

\section{Fertőd, Esterházy Palace,}

\section{Gallery ${ }^{7}$ (Pic. 6)}

er the floor levels in the west wing of the main building has revealed informative details. The aim of ished interior wall structure of this part of the bu known from the visual and written source material even before the beginning of the research that the 18 th century building had been built on a erlier garden, dated aso in the century. Thus, when in a relatively deep ditch, a gas, when in a relatively deep it, the rem wall with plased ween fou ter buing by hom later building, he identification was easy thanks to the sources. It is a good searching for and exploring the remain

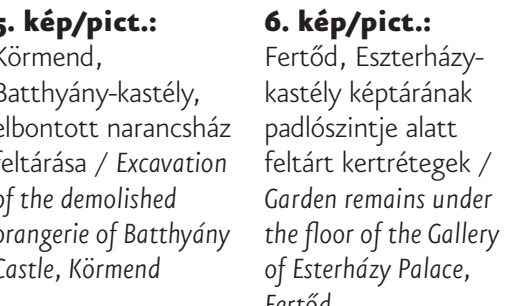

of the environment and garden of the former period under the building that expanded in the later periods.

Szabadkígyós, historic garden of Wenckheim Palace ${ }^{8}$ (Pic. 7) The on-site exploration of the park an the use of the image sources together ed to the identification of some objects. In the park, the presumed location of the ruins of the so-called former dollhouse (with a small idyllic farmhouse character) could be identified in the shrubbery with the help of site drawings of the 1870's. Bricks and remnant of the former exterior plaster marked the location of the building. In the ditch, the walls and floors lying in their original place underneath the humus mixed with debris could be discovred, so the whole structure could be excavated in a way that in situ ils were not further destroyed. The shoreline of the allegedly large the garden, was refect observed in the slightly shrubby area. In a lod trene slghly shrubby a

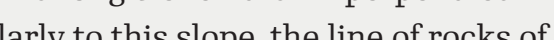
form to this slope, the line of rocks of the ormer shore was revealed, indicating We a lake on was ind We also studied the track of the former paths, some of which could be traced under a thin layer or humus, so we did not need to cut their strucdites with too deep ditches. in small citches, we excruated the fondation f both the built stairs and the pool of
6 Erdélyi Erika-Koppány András: A körmak kutathása (Resesastely narancsházeof the Batthány Castle, Körmend). In:: A Batthyanyak evszazadai (Centuries of the Batthyány Family). Körmend-Szom7 Bulding ace

chaeology of the gallery led by András Koppanany and Mikloss Rác arhaeologists, experts in monume history of the garden was made by Agnes Bechtold and Zita Németh landscape (NöF Nonprofit Ltd.), the onlandscape architect, Zsófia Nádai and Dóra Hegyi archaeologists (Budavári
Nonprofit Ltd.) and András Koppán archaeologist and expert in nophument conservation (MEM-MDK). 


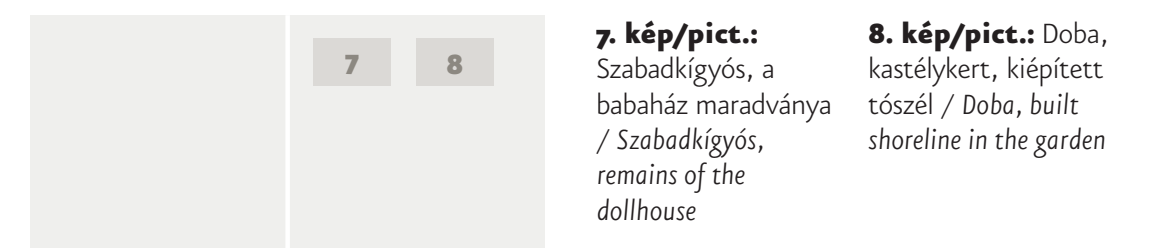

épített lépcsők és a pleasure ground szökőkútmedencéjének alapozására, hogy épített struktúrájukat megismerhessük.

Doba-somlóvári Erdỏdy-kastélypark történeti kertje ${ }^{9}$ (8.kép)

E kastélyparkban az utak építettségük miatt említésre méltó példák. Vaskos, fehér kőzúzalékos, bakhátas kialakításuk jól beazonosíthatóvá tette nyomvonalukat. Az utak fölött képződött vékony humuszréteg eltakarta ugyan felszínüket, ám néhány átvágással hozzávetőle ges vonaluk éppen anyagjuk sajátossá miatt jól megháározható volt. A kivitelezés során, az új rétegrend kialakításak a roncsolt eredeti útfelszín síkban valo bontásakor pontosan kirajzolódott szétenek vonala, amely ́ry egyber ájoct kitüzött útnyomvonal sź́le is azjonn hitur

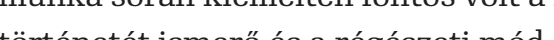
tortenet ismón

A kertben állo un potashazi-to-a

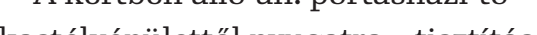
kastélyépulettol nyugatra - tisztitása során kirajzolodot partannak teglafala. A meglepon ép allapotban megmarad támfal strukturaja arra hivja fel a ngy met, hogy egy betemetett tó lokaliza mes épített partszerkezetre számítani.

Nagycenk, Széchenyi-kastély történeti kertje ${ }^{11}$ (9. fotó) A kastélyt övezô történeti kert kutatásának előkészitése során a képi forrásanyagból és a múszeres mérésból sok részlet ismertté vált. Így lehetett régész módszerrel kutatni az épületegyüttes homlokzata elott, a kertben allo egykori, kis méretủ építmény romjait, vagy a parkot határoló, az egykori patakparton álló Lusthaus maradványait. Ez utóbbinál nehézséget jelentett, hogy az épület elbontásakor, a 19. század során igen alaposan jártak el, sígy a maradványok pontos formájának meghatározása alapos és részletes régészeti megfigyelést igényelt; végső soron csak a helyet lehetett gazolni, a pontos alaprajzi formát nem. A kertben csupán a képi forrásanyag alapján volt ismert az egykori barokk kert helye. Így annak középvonalában hoszszanti árkot bontottunk hogy tájéḱzódjunk a történeti kertszerkezet maradváyairól. Az árokban egy nagy mócudvá-

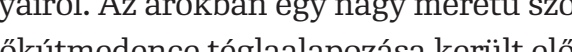
A maradványokon fellelheto a á ŕszeA món részle-

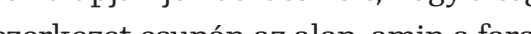
zott bö szoüh az alap, amin a fara-

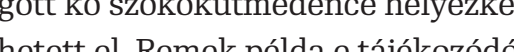

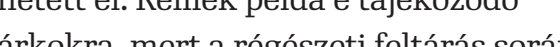
oor , mert a regeszet feltáás során

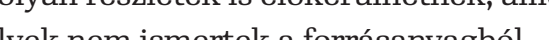
lyek nem ismertek a forrasanyagbol.

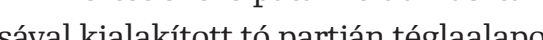
sává kialakitott tó paryan téglaalapozású, nagy méretú kôvekkel, „Sziklaḱkkal boritott dombocska all, kutatása - akárcsak az emlitett szookókútmaradványé - mintegy ötvözte a régészeti és fakutatási módszert, hiszen a rárakódo törmelék és földréteg eltávolítása után struktuurajának, rakásmódjának elemzéját és helyreállitíásának lehetóségeit. ${ }^{12}$
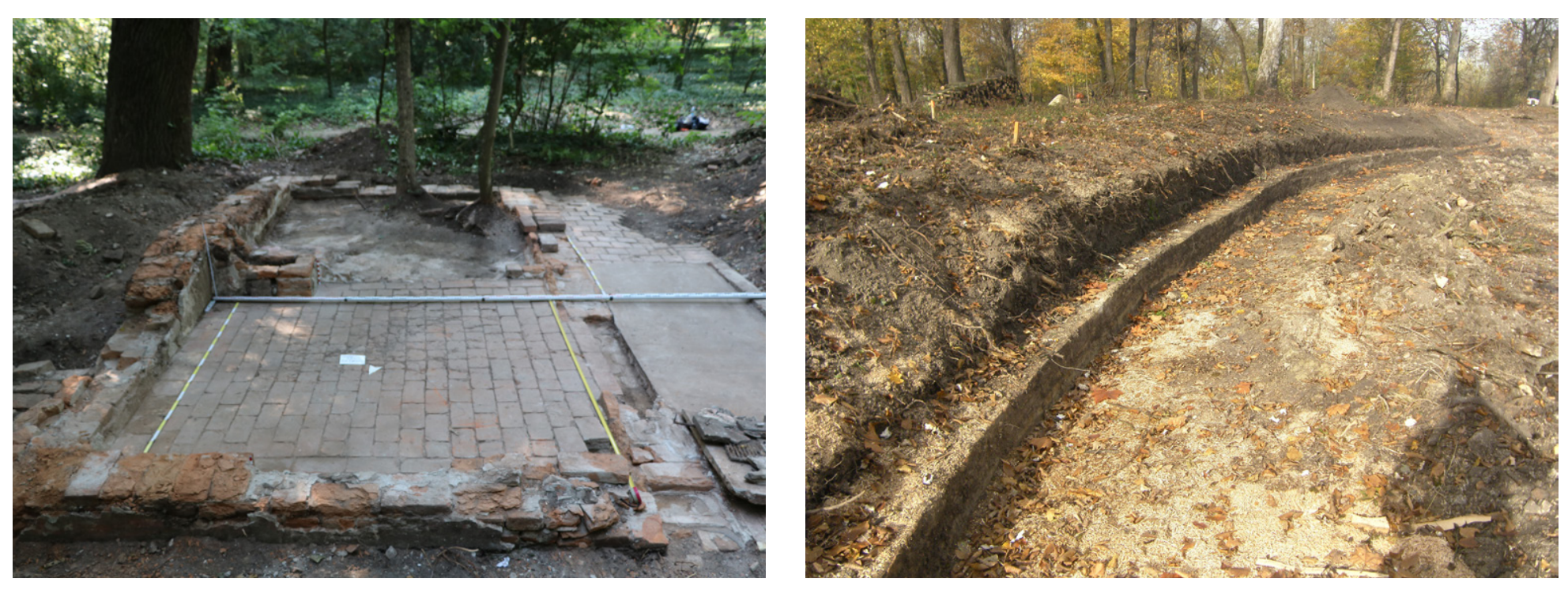

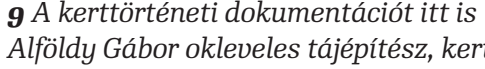
történész készitette.e. A kastélypark tort tortenetéról lés a helyreállitás teleses projektGábor: A doba-somlóvari Erdódy-kastél|ypark, Forster Központ, Budapest, 2015. A helyszini kutatást 2011-ben Fülöp
András régész, müemlékes szakérto, a munka folytatááát 2012-ben Koppány András réét
nyitotta.

10 A kivitelezés ezon szakascát a hely szinen Alföldy Gaboro okleveles tajepités

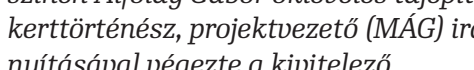
nyitásával végezte a kivitelezzó.
11 A Kerttörténeti Tudományos Do

mentációt Németh Zita és Bechtold Ágnes készitette, a helyszini kertku-
tatást Bechtold Agnes tajepitész (NÖF tatast Bechtold Agnes tajépitészz (NÖF és Büth Mária régészzek (Budavári Kft.) végezték, konzulens Koppány Andras resci, miemes szalerto. 12 A nagycenki kerttel kapcsolatban ld. nyi Ferenc cenki kertiéhez. $4 \mathrm{D}$ Tajépité núvészeti Folyoirat, 2018 . the fountain in the pleasure ground to learn about their built structure.

Doba-Somlóvár, historic garden of Erdôdy Manor House' (Pic. 8)

In this park, the paths are remarkable examples because of their structure Their stout white rubble and ridgeshaped design made their trails well identifiable. The thin layer of humus over the paths covered their surface but due to the nature of their material, their approximate edges were still easy to be defined by excavatin some ditches. When the dxcavating some dit surface was being demolline of the the construction works, the line of the on edges was precis be the of the new setp also po pristory of the gaden and was aware he rof the garder the archaoolog al mis proc was particu larly important at this process. Durng the cleaning of the former lake at the gatehos west from the manor house, the brick wall of the shore unfold . The structing wall, which has remained in a surprisingly intact condition, draws attention to the fact that we should expect built structural elements when locating and exploring the shoreline of a buried lake

Nagycenk, historic garden of Széchenyi Manor ${ }^{11}$ (Pic. 9)

During the preparation of the on-site research of the historic garden, many details became known by analyzing the image sources and results of the geophysical prospections. Thus, it was possible to excavate the ruins of a forme small edifice in front of the facade of the building complex and the remains river bank that bounded the park. In the latter case, a complicating factor was that the building was demolished very thoroughly in the $1 g^{\text {th }}$ century so defining the exact form of the remains required a detailed archaeological observation. Nevertheless, only the location The location of the former Baroque garden was sources. Thus, we opened a longitupresumed midline to find out about the remains of the historic garden dation of a large fountain made of brick was found. Based on the tiny details found on the remains, it was clearly visible that the brick structure was only a base on which the carved stone basin of the fountain may have been installed. This is a good example for is is worth seting up ditches for on ation, as such detais may tur up as not ben On the shor of the lake, whis formed by dan of he lake, which was surrounded the garden, a hill with brickbased large stones was unfolded, the research of which - like the remains of the fountain - combined archaeoogical and building archaeological
9 The scientific documentation of the hisAlföldy landscape architect, a garden historian. A detailed book of the history ruction project was published: Alföldy télypark (The Park of the Erdod'dy-kasDoba-Somlouár). Budapest: Forster Kö̈ pont, 2015; On-site research was led by András Fülöp archaeologist, an expert András Koppány archaeologist an expert in monument conservation in 2012 . 10 This part of the construction work was led by Gabor Affolddy landscape
architect, garden historian, project manager (MÁG). 11 The scientific documentation of the history of the garden was made by Agnes
Bechtold and Zita Németh landscape architects (NÖF Nonprofit Ltd.), the onsite research was led by Ágnes Bechtold Hegyi (Budavari Nonnprofit Ltd.). with András Koppány archaeologist and expert in consultant. 


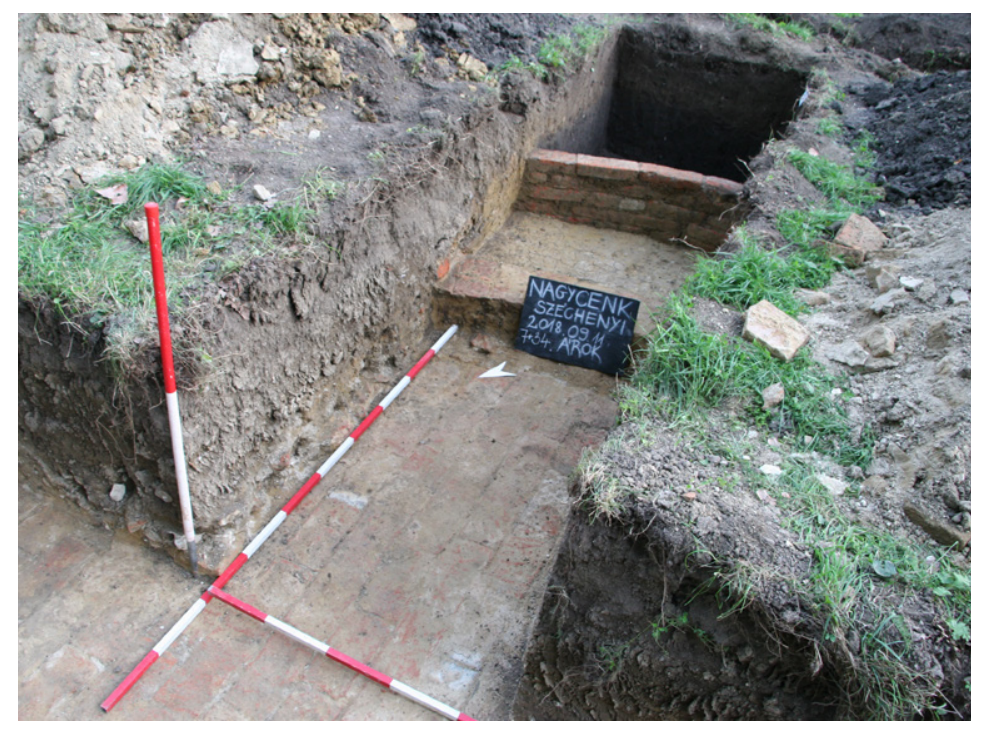

Benczúrfalva, Benczúr-kasté történeti kertje ${ }^{13}$ (1o.kép) A dombtetőn álló kúria épület körül kialakított kis méretú, 2o. század eleji historizáló kertben jól kiépített, az országúttól a kúriaépületéig vezetô, akár gépkocsival is használható utat és jóval egyszerübb kialakítású sétautakat tártunk fel. Utóbbiakat a domboldalba vágva, lépcsőkkel tagolva alakították az épületet övező támfallal megtámasztott teraszból kiindulva. E terasz szelén két apró tornyocska helyezkedik a támfalba illesztve, mintegy kilátópont ként. A kis méretü kö-tégla építón énitésmódiát ́́s a rohtektúń́juk egykori részleteit falkutatással vizgáltuk. Az utak felszínét régészeti módszerAzutak flo vékony humuszréteg eltáviltáś́val.

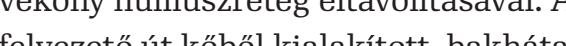

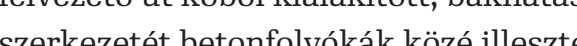
szerk tek. Aho fer kapcsolódott a csap dén

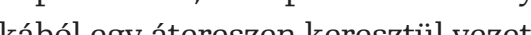
ték továb az ́nzantlakz tek tovább az arcsallakozas alatt. A dombildal kenti lujanak epitetsége csekely vol, elmosódott kavicsszorás jelezte felszinüuet. A szintkulônbségeket áthidaló lépcsoket igen egyszeru kószerkezetek alkottak. Benczúrfalva jó példa arra, hogy egy viszonylag egyszerú módszerekkel kialakitott, kis méretü kertben is érdemes helyszíni kutatást végezni, hogy annak eredménye finomithassa, formáhassa a kertépitészeti rekonstrukciót.

ÖSSZEGZÉS

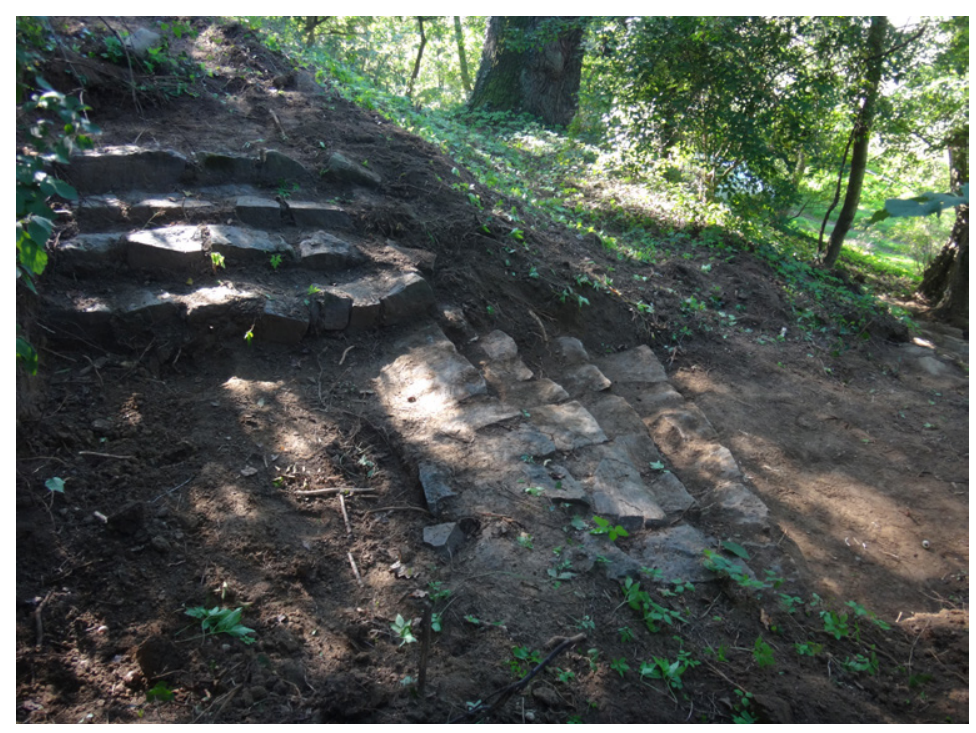

A gyarapodó számú kutatások egyedi tapasztalatai lehetővé teszik, hogy egyre pontosabban „szabhassuk” az adott történeti kertre a kutatást. A különféle szakterületek kutatói által végzett többféle módszerből összeötvözz̋dón gyakorlat biztosíthatja, hogy a kert anyagi valóságában megmaradt részleteinek megismerése, feltárulása és a képi és írott forrásanyag alapján a kerttörténet - az épités átépítés pusztulás folyamata - felvázolható, leírható legyen.

A kerttörténet pedig alapia, kiindulás A kntja lehet a tervezésnek hogy végús felhasználva a vezésnek, hogy végül retet, arra reflekt́ló újegzerzett isme-

13 A helyszíni kutatást Németh Zita és Klagyivik Mária tájépiteszzmérnökök (Nof Nonprofit Kft.) és Koppány Andrós
régesz, múemelékes szakertó iranyyitotrégk

thods, as we interpreted its layout and the possibilities of restoration by analyzing its structure after removing the debris and humus from above.

Benczúrfalva, historic garden of Benczúr Mansion ${ }^{13}$ (Pic. 10)

A well-built road leading from the

highway to the mansion building, which

could even be used by cars, and other,

much more simple garden paths have

been unfolded in the small garden buit

in the early zoth century around the

mansion on the hilltop. The latter were

cut into the hillside, intersected with

ctairs he and there starting for a

starrace supported by a retaining wall

surrounding the building. At the edge

this terrace the be

trach to the reaning wall as belve-

deres. We examined the wonstruction the Wull the selails of their anch with building a with bulding archaeological nethods. The su ce or her primarily by renolo primarily by renoving the thin layer of humus from above. The ridge shaped stone structure of the road was laid At juen concrete drainge channels. At a junction near the highway, the rainwater was led from the channel throu a culvert under the junction of roads. The structure of the garden paths on the hillside was very weak, only the scatered gravel indicated their surface. Th stairs bridging the height differences were very simple stone structures.
9. kép/pict.:

Stélypark,

Nagycenk, remains of

Benczúrfalva, kerti

lépcső maradványa / in the garden in in the garden in
Bencuúfflua
Benczúrfalva is a good example of the fact that it is worth doing on-site research in a relatively simple small garden as well because its results can refine and give additional details for the reconstruction of the garden.

\section{SUMMARY}

The unique experiences of the growing number of researches make it possible to specify research more and more accurately to the particular historic garden. The research practice combined from a variety of methods, carried out y researchers from different discithe garden - processes of construcation and destruction can be described, based on the exploration of remained garden details and ime detals and The history of the garden

urthermore, is the basis, the starting point of preserving our garden heritage, f conservation and reconstruction plans that reflect on the knowledge gained rom the old possibly with authentic restorations.
See the publication of Borbala Mohay Supplements to current research on the enchitecture and 13 . architects (NÖF Nonprofit Ltdd) and An rás Koppány archaeologist, expert in monument conservation 